\title{
RETRO-INNOVATION AND CORPORATE SOCIAL RESPONSIBILITY
}

\author{
Loucanova Erika \\ Technical University in Zvolen, The Faculty of Wood Sciences and Technologies, \\ Department of marketing, trade and world forestry, Slovak republic \\ loucanova@tuzvo.sk \\ Parobek Jan
}

Technical University in Zvolen, The Faculty of Wood Sciences and Technologies,

Department of marketing, trade and world forestry, Slovak republic parobek@tuzvo.sk

\section{Kalamarova Martina}

Technical University in Zvolen, The Faculty of Wood Sciences and Technologies, Department of marketing, trade and world forestry, Slovak republic martina.kalamarova@tuzvo.sk

(Received July 2015; accepted September 2015)

\begin{abstract}
The paper deals with the retro-innovation and their importance to corporate social responsibility (CSR). Corporate social responsibility is a process with the aim to encourage a positive impact through activities on the environment, consumers, employees, communities, and all other stakeholders of the public sphere. The accelerated rate of technological and social change influences on the society. The main social problems are symptoms of future shock. Retro-innovation trend is emerging against an accelerating backdrop of "datafication". New products are designed to connect customers with the past in ways that are nostalgic, interactive and environmental. CSR thanks to the retroinnovation encourages has a positive impact on the all stakeholders and eliminates the future shock.
\end{abstract}

Key words: corporate social responsibility, future shock, retro-innovation.

J.E.L. CODES: M14, O12, O31.

\section{Introduction}

The modern history of corporate social responsibility (CSR) has started last century in the fifties. The idea of corporate responsibility has been involved to the literature for managers. The first definitions of CSR were based on management pattern, and showed its embattled position. Howard R. Bowen (1953) considers social responsibility as a business commitment to pursue strategies that are required in terms of objectives and values of our society (Archie, 1999). Corporate social responsibility is a process with the aim to encourage a positive impact through activities such as the retro-innovation. The retro-innovation has a positive impact on the all stakeholders CSR. The aim of the paper is the retro-innovation and their 
Loucanova, E., Parobek, J., Kalamarova, M. (2015)

Retro-innovation and corporate social responsibility

importance to corporate social responsibility (Corporate social responsibility, 2013).

\section{Literature review}

Many authors recognise CSR as conscience of the company, citizenship and social power. On the other side sustainable responsible business is a corporate selfregulation form integrated into a business model (Wood, 1991). CSR can be defined as a built-in, self-regulating mechanism which the company use for monitoring and for ensuring active compliance with the legislation and ethical standards.

CSR is a process to take responsibility for the company's activities and encourage a positive impact on the environment, consumers, employees, society, and all other stakeholders (Freeman, 1984). The concept of corporate social responsibility is not yet clearly defined and offered various interpretations, providing the widest possibilities of practical use (Bussard et al., 2013).

The accelerated changing of technological and social development makes people stresses as well as shocks. This social problem is a symptom called as "future shock". The shock of the future is characterized as a need and inability to adapt ongoing changes. Toffler (1990) defined it as a phenomenon associated with the time and described it as the result of the rapid pace of change in society, figure 1 (Toffler, 1990; Future Shock, 2013).

Figure 1. The accelerated pace of technological and social changes resulted in "Future Shock"

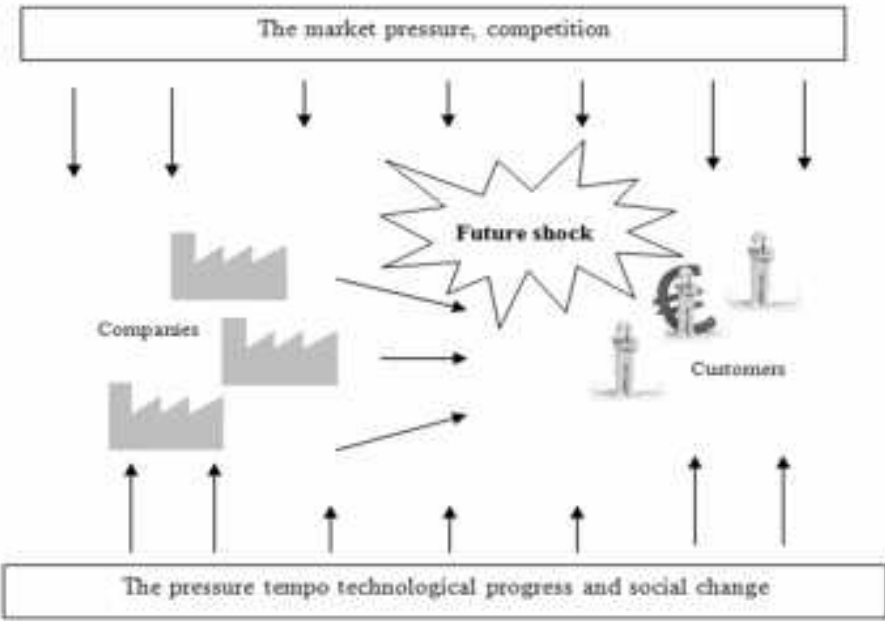

Source: Loucanova, Parobek, 2013. 
New products and services are designed to be able combine approaches from the past that are nostalgic and interactive for environment and present life. This approach leads to a unique type of innovation in technologies, in new products or experiences that are designed to linking consumers to the past. We call them as retro - innovation. At the present time, there is the tendency towards retro innovation thank to the "Business Data" and the increasing changing on the market (Leberecht, 2013). As say Walburn (2014) "not all innovation needs to be about high tech to contribute to economic growth, and much innovation can be achieved from drawing on existing technologies, or re-visiting former ways of doing things". This kind of innovation is trying to eliminate social shock of the future (Supín, 2009). CSR through retro - innovation supports the positive impact of activities on customers, employees, communities and is trying to eliminate shock to the future. Retro - innovation focus on an area that is crucial in terms of CSR and many times is underestimated. The pressure of society and technological progress has direct influence on the amount of personal, career and other problems. The speed of change currently generates a lot of pressure on the customers and they intuitive make reject innovation.

Figure 2 The force field of innovations

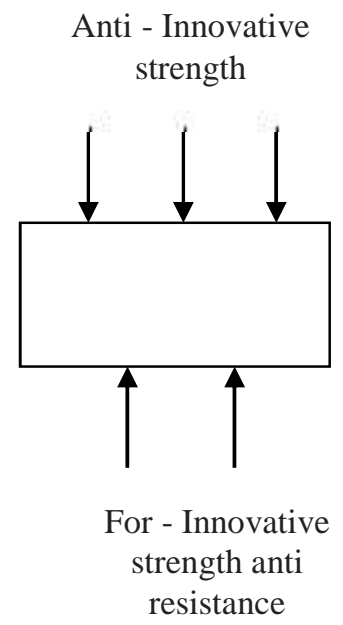

Innovative movement

Equilibrium

Source: author's view by Kovac, 2003.

\section{Material and methods}

We used analytical and synthetic methods that connect approaches to the issue of retro-innovation in the corporate social responsibility. Through the analysis of phenomena and processes we analyzed the issue of retro-innovation and corporate 
social responsibility. We analyzed this issue by individual parts using the descriptive method; we described their relationships to identify innovation, retroinnovation, future shock and corporate social responsibility on the observed level.

\section{Results and discussion about Relationship between retro-innovations and CSR}

Implementation of retro-innovation management is a complex process where CSR is mainly focused on one of components. On the other hand it is social responsibility of companies (SRC) to customers, employees and owners. Thereby retro innovation is affecting the economic, environmental and institutional dimensions of CSR (Figure 3).

Figure 3 Dimension CSR

Source: Sakal, 2011.

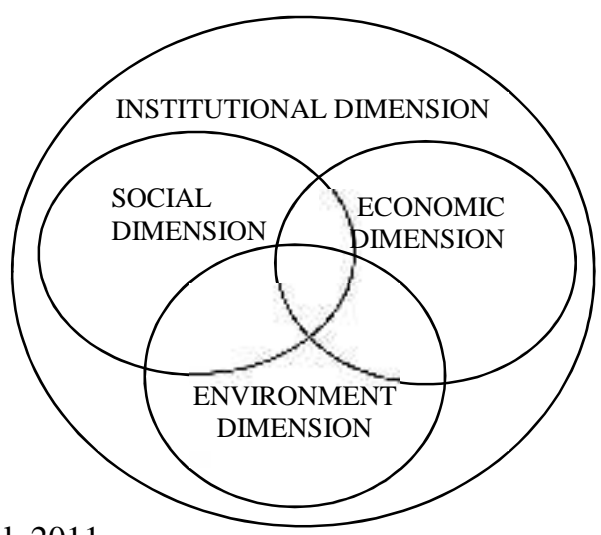

The force of the market by applying innovation and the pressure of rejection customers, is described in Figure 2 (exposure to and against innovative forces in the force field caused the formation of retro - innovation). Innovations as well as customers and companies are subjected to forcible field. Pressure creates market power, management of change, competition and many other factors.

Today, the predominant high level of technology and mechanization leads to a high level of production with a high level of capital investment. That causes fast development of new innovations, which does not necessarily have to have a positive effect on market participants, not only customers but also companies. As a consequence of this fact, some innovations may be rejected.

In relation to a constant growth of market and possibility of rejection of innovations, there arise new tendencies towards retro - innovations, which are 
Loucanova, E., Parobek, J., Kalamarova, M. (2015)

Retro-innovation and corporate social responsibility

realized on the basis of $3 \mathrm{C}$ - customers, competition and change, which is brought by innovation.

Because as Leberecht (2012) said: „People don't want to innovate. They want to dream, empathize, bond, do the right thing, and create."

New goods and services are, therefore, designed in such a way that they connect us with the past. This extraordinary type of innovations - new products, technologies and experiences connected to the past - may be called retro - innovations.

Retro - innovations are related to rediscovery of an old knowledge, procedures and traditions, which are considered forgotten. It is a combination of historical knowledge from the history and the present, it is a mutual interconnection and it will be used in the future.

Retro - innovation represents the creation of something unique and new, which will connect current modern world with the past.

It might seem that retro - innovations do not have anything to do with CSR, however, the opposite is true. Retro - innovations pay attention to the areas that are often underrated. It is the pressure on an individual from the society, technological progress and accelerated pace of change that causes a lot of personal, professional and other problems in society, influencing the phases of family life cycle and, overall, influencing the whole generation.

Many authors argue that CSR activities distract from the economic role of businesses. On the other side McWilliams and Siegel (2000) have shown that correctly specified model of CSR has a neutral effect on financial results. One of the tools which can right specific model of CSR is retro - innovation. In that sense it is a complex process of long term business (Palus, Salka, 2004) in the relationship between social and financial performance of the company. This issue represents the emergence of successive innovations. Simultaneously, it lunches innovation in a form which is already known to customers but is supplemented with new elements, components and functions. These kinds of innovations are derived from the known not only to the customer but also the company. Applying them to ensure the elimination of social pressure to adapt a revolutionary innovation that customers may (but also companies) to cause the shock of the future. Customer knowledge aligns more with a new product. The company increased the success via introduction of product which are already knows to the market. This approach helps to companies reduce and eliminates the shock of future.

Retro - innovation constitute an entirely new concept in innovation management, just point to a good run in systems that have not yet been defined. This can be considered by a unique kind of innovation - new technologies, new products or experiences that are designed to connecting consumers with the past. Against an accelerating backdrop of datafication, a "retro-innovation" trend is emerging. New 
Loucanova, E., Parobek, J., Kalamarova, M. (2015)

Retro-innovation and corporate social responsibility

products and services are designed to connect with the past in ways that are both nostalgic and interactive. Retro Innovations roughly fall into three categories:

- Innovations that authentically mimic a product or experience of the past to transport the user back into a gone era.

- Innovations that use a nostalgic format to meet a new need.

- Innovations that use a new format to meet an old need (Chunduri, 2013).

It seems as non-innovative approach, but as some authors Frei (2008) Chunduri (2013) mentioned Retro innovation (2013) or Retro-Innovation: Is Nostalgia The Next Big Thing (2013) really works. Instead of focusing entirely on new less more successful products or markets it is focused on opportunities. During crisis retro less cost innovation and ensures success are important from the perspective of corporate social responsibility and cause the shock of the future for the stakeholders.

Savings many thanks to innovation with the knowledge about old markets and products customers regards as important issue. The customer may not even notice, why and how a new product so quickly adopted. That adaptation has the same positive impact on the business and on staff and at the same time helps to make lower production costs. In the same time it represents less venture capital and faster return on investment in innovation.

Retro - innovations positively influence activities, mainly those of the customers, employees, community and they eliminate the shock from the future. On one side, there is the influence of the pressure of the market offering the innovations and, on the other side, there is the pressure from rejection of customers. It is customers who don't stand the pressure. Thus, pros and cons of innovative powers are applied in the power field of innovations. Naturally, these complicated interconnections have created environment suitable for creation of so called retro - innovations.

Realization of management of retro - innovations is a complex CSR process but it is mostly focused on social responsibility of enterprises towards their customers, employees and, what is interesting, also towards the owners of the enterprises as it has an effect on economic, environmental and institutional dimension of CSR.

Many critics of CSR argue that activities of CSR types divert attention from economic functions of companies. However, McWilliams and Siegel (2000) proved that if the CSR model is set in a right way, it has a neutral effect on financial results. One of the tools for correct specification of the CSR model is involvement of retro - innovations into the complex process of long - term perspective of doing business in relationship between social and financial performance of the given business. By completing of information, it is easier for customer to become more familiar with a new product and company offering this kind of product is more likely to be successful as it knows its market, customer, 
competition and it is able to decrease its risk capital and to eliminate the shock from the future. Retro - innovations do not represent a totally new concept in innovation management, they only point to already proved and well - known systems, which have not been defined as retro - innovations yet. This sentiment is reflected in the products of experienced customers, too.

Retro - innovations eliminate the market risk by its empathy towards the customers and by their gained experiences with old and well - known markets. Retro innovation is not that demanding and expensive for research and development and so it is more acceptable for many companies. Retro - innovations do not have to be old - fashioned and inefficient at all. Not everything what is new and modern on the market must be necessarily successful. Instead of being focused on new products and markets we should focus more on opportunities, which secure the success, which are not so expensive and, which eliminate the shock from the future.

Some large companies even have not capital that is why innovation become unrealistic for them. However, the retro - innovation by its smaller intensity are available to all companies. Thanks to low expensive to research and development introductory price on the market is more accessible to customers.

Such an understanding of corporate social responsibility through retro - innovation brings:

- reduction market pressure and pace of social currency,

- elimination the shock of the future and meeting the social dimension of corporate social responsibility,

- reduction costs in various areas, thereby promoting the economic dimension of CSR,

- continuous innovation process of products with retro-innovations provides increased performance in sustainable use of resources of the region, known business environment, reducing financial intensity of innovation process and so on,

- retro-innovation support ensures competitiveness based on high-quality and continuous improvement of the products, figure 4 (Loucanova, 2014), thereby promoting the economic, social, environment dimension of CSR,

- represent business opportunities for the sustainable use of resources that through innovations create conditions for sustainable growth of the competitiveness of enterprises (retro-innovations does not present completely new concept, it just mentions well-established and running system), thereby promoting the economic dimension of CSR, 
Loucanova, E., Parobek, J., Kalamarova, M. (2015)

Retro-innovation and corporate social responsibility

- infectivity and omissions stages of the retro - innovation process, which would have an impact on the environment, it also supports the environmental dimension of CSR (figure 5).

Figure 4 The continuous innovation strategy of retro-innovations

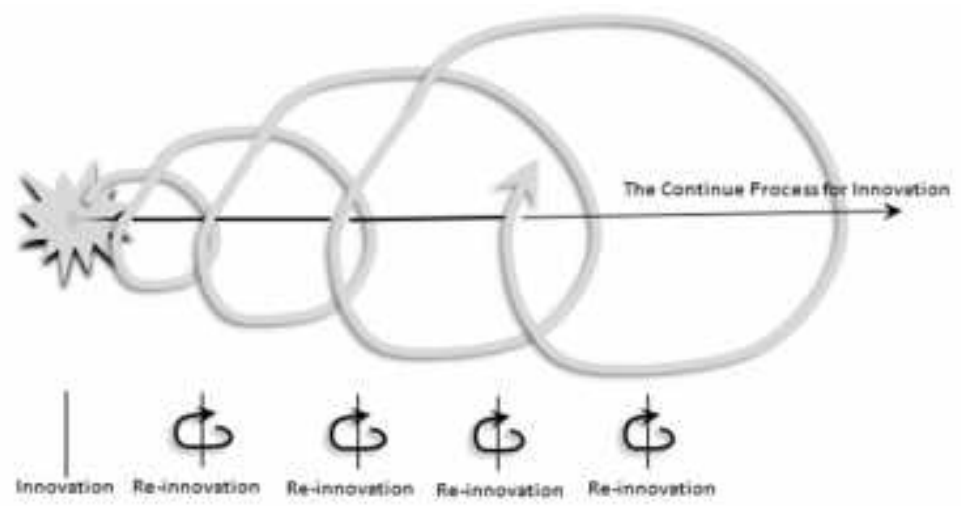

Source: Loucanova, 2014.

Figure 5 Retro-innovation and their importance in corporate social responsibility

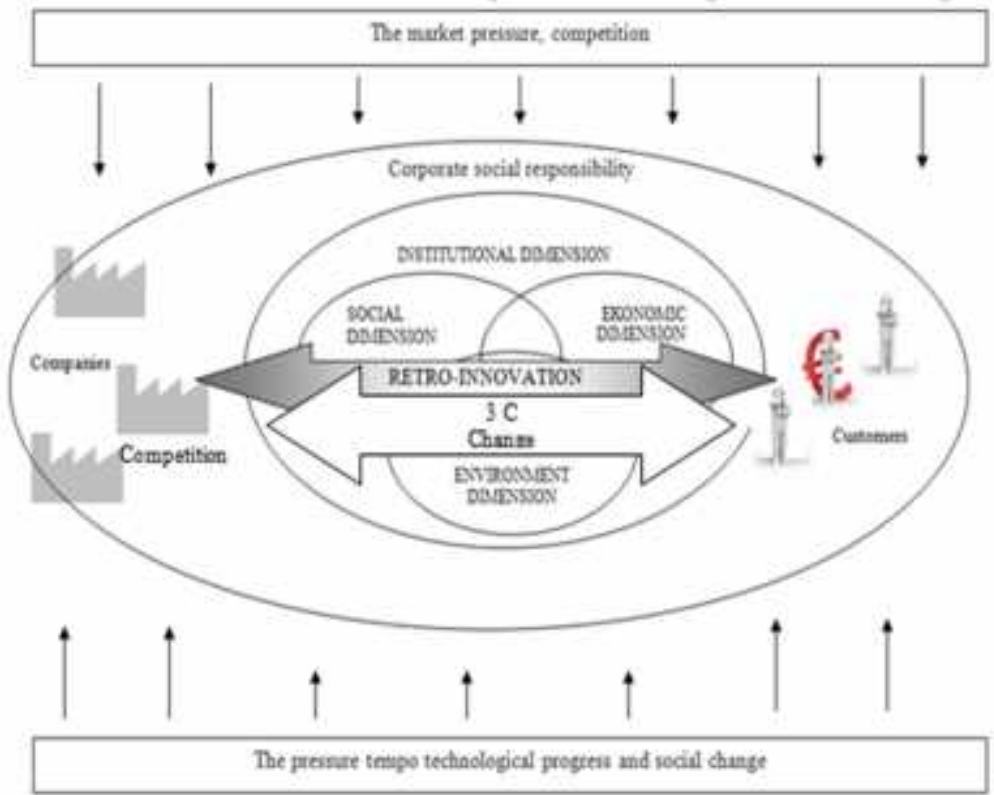

Source: author's view 


\section{Conclusions}

CSR is not yet clearly defined concept and offers various interpretations, thus providing space for the widest possibilities of practical use. CSR requires innovation than any other area of business. At the same time innovation require inspiration, creativity, discipline and sometimes a lot of luck. It is necessary to choose your options carefully to be successful. Retro-innovation tries this component relative success of innovation eliminated through the use of retro elements in innovation, which spread across all dimensions of CSR. Retroinnovation is a way to be competitive in the global market in times of crisis with respect to all stakeholders.

\section{Acknowledgement}

The author would like to thank the Scientific Grant Agency of the Ministry of Education, Science, Research and Sport of the Slovak Republic and the Slovak Academy of Sciences. This paper was elaborated within the frame of Grant project 1/0387/13 A comprehensive model of wood chain comparative advantages.

\section{References}

1. Archie, B. C. (1999). Corporate Social Responsibility. Evolution of the Definitional Construct. Business \& Society, Vol 38 No. 3, 268-295.

2. Bussard A., Marcek E., Markus M., Buncak M., Mazurkiewicz P. (2013). Spolocensky zodpovedne podnikanie (on-line) www.employment.gov.sk/csrnahlad-vseobec.-dobry.pdf Accessed 10.10.2013

3. Chunduri, CH. (2013) Marketing Nostalgia - Retro inovacie (on-line) https://medium.com/noise-branded/b542fbbe406e Accessed_16.09.2013

4. Corporate social responsibility (2013) (on-line) http://en.wikipedia.org/wiki/ Corporate_social_responsibility Accessed_12.10.2013.

5. Freeman, R. E. (1984) Strategic management: a stakeholder approach. Boston: Pitman.

6. Frei, B. (2008) Why retro innovation is the most lucrative kind (on-line) http://venturebeat.com/2008/04/21/why-retro-innovation-is-the-most-lucrativekind/ Accessed 15.09.2013

7. Future Shock (2013) (on-line) http://en.wikipedia.org/wiki/Future_Shock. Accessed 11.10.2013

8. Kovac, M. (2003). Inovacie a technicka tvorivost'. Kosice: TU Kosice (on-line) https://www.sjf.tuke.sk/ktam/oav/obrazky2/e-texty/_skripta/inovacie.pdf Accessed 15.09.2003 
9. Leberecht, T. (2012) 5 Keys To Building A Business That Doesn't Bury The Humans At Its Core. http://www.fastcodesign.com/1669988/5-keys-to-building-abusiness-that-doesnt-bury-the-humans-at-its-core Accesed 02.11.2013

10. Leberecht, T. (2013) Back To The Future: Why Retro-Innovation Is The Next Big Thing (on-line) http://www.fastcodesign.com/1672508/back-to-the-future-whyretro-innovation-is-the-next-big-thing Accessed_15.09.2013

11. Loucanova, E. (2014) Retro-innovations as an important element of the current innovation policy. (online) http://www.know-hub.eu/knowledge-base/videos/retroinnovations-as-an-important-element-of-the-current-innovation-policy.html Accessed 3.3.2015

12. Loucanova, E., Parobek, J. (2013). Retro-inovacie a ich vyznam pre spolocensky zodpovedne podnikanie. Marketing Identity, 2013. 270-280.

13. Loucanova, E., Trebuna, P., Palus, H. (2014) Retro na sucasnom trhu a retroinovacie. In Transfer inovacii 29, 108-112.

14. McWilliams, A., Siegel, D. (2000) Corporate social responsibility and financial performance: correlation or misspecification? Strategic Management Journal 21 (5), 603-609.

15. Palus, H., Salka, J. (2004) Inovacne siete na priklade odvetvi LH a DSP v SR. Podpora inovacii a podnikania v lesnictve, 2004, 47-55.

16. Retro-Innovation (2013) (on-line) http://smartketingreflections.blogspot.sk/ 2013/01/retroinnovation.html\#.UkpiWmxwcdU Accessed 30.09.2013

17. Retro-Innovation: Is Nostalgia The Next Big Thing? (2013) (on-line). The Business Romantic. http://timleberecht.tumblr.com/post/47713794379/retroinnovation- is-nostalgia-the-next-big-thing Accessed_16.09.2013

18. Sakal, P. (2011). Koncept HCS modelu 3E vs. koncept Corporate Social Responsibility (CSR). (on-line) http://www.scss.sk/index.php?categoryid= 1\&p2_articleid=14. Accessed 13.10.2013

19. Supin, M. (2009) Megatrendy vo vyvoji svetoveho hospodarstva a moznosti Slovenskej republiky zmakcit dosledky hospodarskej krizy. Marketing a obchod 2009 : vplyv hospodarkej krizy na marketing a obchod. 5-8.

20. Toffler, A. (1990) Future Shock. New York: Bantam Books, 1990.

21. Walburn, D. (2014) Expert's comments by Retro-innovations as an important element of the current innovation policy In KNOW-HUB (online) http://www.know-hub.eu/knowledge-base/videos/retro-innovations-as-animportant-element-of-the-current-innovation-policy.html. Accessed 3.3.2015 22. Wood, D. 1991. Corporate Social Performance Revisited. The Academy of Management Review 16 (4), 691-718. 